\title{
Efektivitas Pembelajaran Online melalui Aplikasi Edmodo pada Mata Kuliah Ekologi Hewan
}

\author{
Novelina Andriani Zega \\ (Prodi Pendidikan Biologi, FPMIPA IKIP Gunungsitoli, Sumatera Utara) \\ * Corresponding-Author. Email: andrianizega84@gmail.com
}

Receive: 18/08/2021

Accepted: 23/09/2021

Published: 01/10/2021

\begin{abstract}
Abstrak
Penelitian ini untuk mengetahui pengaruh penggunaan aplikasi edmodo terhadap efektivitas pembelajaran mahasiswa pendidikan biologi. Penelitian ini merupakan experiment semu (Quasi Experimental Design). Desain yang digunakan dalam penelitian ini adalah posttest only control design. Populasi dalam penelitian adalah seluruh mahasiswa semester VI prodi pendidikan biologi IKIP Gunungsitoli angkatan 2020/2021 berjumlah 72 orang. Sampel terdiri dari 2 kelas dimana kelas 1 adalah kelas experimen dibelajarkan menggunakan aplikasi edmodo dan kelas 2 adalah kelas kontrol dibelajarkan tanpa menggunakan aplikasi edmodo. Instrumen dalam penelitian ini adalah lembar observasi, angket dan soal posttest. Hasil penelitian menunjukkan bahwa terdapat pengaruh penggunakan aplikasi Edmodo terhadap efektifitas pembelajaran, hasil tes menunjukkan ketuntasan klasikal sebesar $84 \%$ pada kelompok yang menggunakan aplikasi Edmodo, sehingga dapat disimpulkan pembelajaran menggunakan aplikasi edmodo efektif dalam dalam kegiatan perkuliahan.
\end{abstract}

Kata kunci: Pembelajaran online, edmodo, ekologi hewan

\begin{abstract}
This study was to determine the effect of using the Edmodo application on the learning effectiveness of biology education students. This research is a quasi-experimental (quasi experimental design). The design used in this study is a posttest only control design. The population in the study were all students of the sixth semester of the biology education study program at IKIP Gunungsitoli class of 2020/2021 totaling 72 people. The sample consists of 2 classes where class 1 is an experimental class taught using the Edmodo application and class 2 is a control class taught without using the Edmodo application. The instruments in this study were observation sheets, questionnaires and posttest questions. The results showed that there was an effect of using the Edmodo application on the effectiveness of learning, the test results showed classical completeness of $84 \%$ in the group using the Edmodo application, so it can be concluded that learning using the Edmodo application is effective in lecture activities.
\end{abstract}

Keywords: online learning, edmodo, animal ecology

\section{Pendahuluan}

Permendikbud No. 49 Tahun 2014 tentang Standar Nasional Pendidikan Tinggi, telah mengharuskan sistem pembelajaran di perguruan tinggi berbasis pada capaian pembelajaran (Pasal 5, 6, 7), serta proses pembelajarannya memiliki karakteristik yang mencerminkan sifat interaktif, holistik, integratif, saintifik, kontekstual, tematik, efektif, kolaboratif, dan berpusat pada mahasiswa (Pasal 11 ayat (1)). Oleh karena itu pola pembelajaran di perguruan tinggi yang terpusat pada dosen (Teaching Centered Learning) dinilai 
sudah tidak memadai lagi, dan harus diubah menjadi berpusat pada mahasiswa (Student Centered Learning).

Setiap saat pengajar di seluruh dunia selalu mencari tahu cara yang paling efektif agar siswa dapat belajar dengan lebih baik dan juga meubuat siswa lebih cepat mamahami sesuatu. Sudah banyak sekali strategi belajar mengajar yang telah diterapkan di institusi dasar maupun institusi tinggkat tinggi. Hal ini berdampak kemajuan pendidikan yang lebih baik daripada puluhan tahun (Yustianingrum, 2018).

Banyak hal yang telah berubah seperti munculnya animasi pembelajaran, munculnya media pembelajaran yang semakin praktis dan semakin mudah diterapkan di kelas. Saat ini bahkan sudah ada laboratorium virtual sehingga bisa dilakukan pembelajaran yang lebih efektif terutama pemanfaatan waktu. Salah satu hal yang bisa dilakukan di Indonesia adalah pembelajaran online dengan berbantuan aplikasi, sehingga mempermudah dalam pelaksanaan pembelajaran dan pemberian nilai (Darmawan, 2014).

Aplikasi yang cukup terkenal di dunia adalah aplikasi Edmodo yang telah digunakan pelajaran hingga jutaan orang. Namun tidak semua kondisi cocok untuk digunakan aplikasi Edmodo seperti wilayah yang belum tersedia internet dengan baik. Pelajar yang belum terbiasa menggunakan aplikasi online untuk belajar di sekolah. Oleh karena itu penelitian ini berfungsi untuk mendapatkan bukti empiris pengaruh penggunaan aplikasi edmodo terhadap efektivitas belajar mahasiswa pendidikan biologi di IKIP Gunungsitoli.

Media jejaring sosial Edmodo lahir setelah media jejaring sosial Facebook berkembang pesat jumlah penggunanya. Hampir setiap orang yang memiliki jaringan internet, baik komputer (PC), laptop, tablet, atau ponsel pasti mengenal dan mungkin memiliki account Facebook. Edmodo diciptakan oleh Nic Borg dan Jeff O'Hara pada akhir tahun 2008. Borg \& O'Hara menyadari kebutuhan lingkungan sekolah untuk berkembang memenuhi tuntutan dunia abad ke21. Keberhasilan platform jejaring sosial sebelumnya, seperti MySpace dan Facebook, menunjukkan bahwa banyak siswa sebagai pengguna media jejaring sosial tersebut tetapi aktivitas mereka tidak terhubung dengan belajar dan pembelajaran di sekolah. Borg \& O'Hara percaya bahwa jejaringan sosial diarahkan pada kebutuhan peserta didik bisa memberi dampak besar terhadap bagaimana mereka berkolaborasi, dan belajar dalam dunia mereka, daripada mengandalkan setting guru mereka di sekolah (Vania, dkk., 2018).

Jadi bisa dikatakan bahwa Edmodo merupakan media jejaring sosial yang dipersiapkan untuk belajar dan pembelajaran bagi guru dan siswa, dosen dan mahasiswa, sehingga tercipta sistem pembelajaran yang inovatif, kreatif, efektif, dan menyenangkan. Terbukti, lebih dari 18 juta pengguna (2008-2013), Edmodo berhasil mengumpulkan pujian dari guru dan siswa. Guru menggunakan Edmodo untuk mengirim pengumuman dan tugas bagi siswa mereka. Siswa menggunakan Edmodo untuk berkomunikasi dengan guruguru mereka untuk bertanya tentang pelajaran dan pekerjaan rumah, dan berkolaborasi dengan sesama siswa pada kegiatan dan ide-ide proyek. Di samping itu lingkungan Edmodo bebas dari iklan, game, dan gangguan lain yang mungkin mengganggu belajar siswa (Zamrotul \& Durinta, 2015).

Edmodo merupakan situs jejaring sosial berbasis lingkungan kampus (School Based Environment). Edmodo diciptakan menggunakan konsep social networking, yang mengacu pada jejaring sosial Facebook sehingga sistem ini memiliki fitur yang mirip dengan Facebook. Edmodo adalah jejaring sosial terbatas dengan guru sebagai pusatnya. Murid dapat masuk ke dalam sebuah siklus di Edmodo hanya apabila diundang oleh gurunya Oleh karena itu, murid tahu bahwa orang-orang yang ada di circle tersebut hanyalah teman-teman sekelasnya. Semua orang di Edmodo adalah 
anonimus, termasuk guru, karena itulah semua orang bisa dengan bebas mengemukakan komentar, pertanyaan, jawaban, ide dan pendapat tanpa harus khawatir mempermalukan diri sendiri (Mitakh \& Samsi, 2015). Agar suasana di circle Edmodo tetap kondusif, guru akan menjadi semacam pengawas. Guru dapat memberikan poin untuk murid pengguna yang pendapatnya bagus dan berguna. Guru juga dapat memberikan hukuman kepada murid pengguna yang tidak sopan atau mengganggu. Kemudian dalam Edmodo tidak boleh ada singkatan-singkatan semacam bahasa SMS atau twitter. Bahasa yang digunakan harus formal dan jelas. Orang tua murid juga bisa bergabung di circle Edmodo anaknya (Dharmawati, 2017; anggraini, Muharini, \& Lestari, 2018).

Efektivitas pembelajaran secara konseptual dapat diartikan sebagai perlakuan dalam proses pembelajaran yang berdampak pada keberhasilan usaha atau tindakan terhadap hasil belajar peserta didik. Keefektifan program pembelajaran ditandai dengan ciri-ciri sebagai berikut:

a. Berhasil menghantarkan siswa mencapai tujuan-tujuan instruksional yang telah ditetapkan.

b. Memberikan pengalaman belajar yang atraktif, melibatkan siswa secara aktif sehingga menunjang pencapaian tujuan instruksional.

c. Memiliki sarana-sarana yang menunjang proses belajar mengajar.

Efektivitas pembelajaran ialah proses pembelajaran yang mencapai hasil belajar sesuai dengan tujuan pembelajaran yang telah ditetapkan (Sugiyono, 2018). Salah satu indikator indikator efektivitas hasil belajar adalah nilai yang dapat diperoleh dari nilai tes (aspek kognitif).

Suatu pembelajaran dikatakan efektif apabila memenuhi persyaratan utama keefektifan, yaitu 1) presentasi waktu belajar siswa yang tinggi dicurahkan terhadap kegiatan belajar mengajar, 2) ratarata perilaku melaksanakan tugas yang tijjnggi diantara siswa, 3) ketetapan antara kandungan materi ajaran dengan kemampuan siswa diutamakan, dan 4) mengembangkan suasana belajar yang akrab dan positif. Untuk mengukur keefektifan suatu pembelajaran dapat dilakukan dengan memberikan tes kepada peserta didik. Hal ini dikarenakan tes dapat digunakan untuk melakukan evaluasi berbagai aspek pengajaran.

\section{Metode}

Jenis penelitian ini merupakan penelitian experimen semu (quasi experimental design) dengan memberikan perlakuan khusus yakni berupa penggunaan aplikasi edmodo untuk kelas experimen dan tanpa perlakuan khusus untuk kelas control. Penelitian ini melibatkan dua kelompok mahasiswa, yaitu satu kelompok sebagai kelompok eksperimen (percobaan) dan satu kelompok sebagai kelompok kontrol (pembanding). Kelompok eksperimen diajar dengan menggunakan edmodo sedangkan pada kelompok kontrol tanpa menggunakan edmodo.

Desain penelitian yang digunakan dalam penelitian ini adalah posttest-only control design. Desain penelitian digambarkan pada tabel 1 .

Tabel 1 Desain Penelitian

\begin{tabular}{|c|c|c|}
\hline Kelompok & Perlakuan & Posttest \\
\hline $\mathbf{1}$ & $\mathrm{X} 1$ & $\mathrm{Q}$ \\
\hline $\mathbf{2}$ & $\mathrm{X} 2$ & $\mathrm{Q}$ \\
\hline
\end{tabular}

Keterangan :

1 : Kelompok Experimen

2 : Kelompok Kontrol

$\mathrm{X}_{1}$ : Perlakuan pembelajaran menggunakan aplikasi edmodo

$\mathrm{X}_{2}$ : Tanpa perlakuan pembelajaran menggunakan aplikasi edmodo

Q : Posttest

Penelitian ini dilaksanakan di IKIP Gunungsitoli. Penelitian ini dilaksanakan selama 4 kali pertemuan di kelas. Populasi dari penelitian ini adalah seluruh mahasiswa angkatan 2020/2021 semester 6 yang memprogram mata kuliah ekologi hewan. Teknik sampling yang digunakan 
adalah sampling jenuh yaitu penggunaan seluruh populasi menjadi sampel sehingga terpilih sampel penelitian ini adalah mahasiswa kelas kelas 1 sebagai kelas eksperimen yang dibelajarkan menggunakan edmodo dan kelas 2 sebagai kelas control yang dibelajarkan tanpa menggunakan edmodo. Total sampel sebanyak 72 mahasiswa.

Cara mendapatkan data yang dibutuhkan untuk penelitian ini digunakan teknik pengumpulan data menggunakan instrument tes, dan lembar observasi. Teknik analisis data yang digunakan dalam penelitian ini adalah statistik deskriptif dan statistik inferensial. Statistik deskriptif untuk mengetahui skor dan membuat pengkategorian variabel terikat yaitu efektivitas pembelajaran. Statistik inferensial digunakan untuk menguji hipotesis penelitian, dianalisis menggunakan aplikasi SPSS.

Teknik pengumpulan data dalam penelitian ini dilakukan dengan pemberian tes hasil belajar belajar kepada masingmasing setiap kelompok mahasiswa (eksperimen dan kontrol). Pemberian tes dilakukan setelah kedua kelompok diberikan perlakuan (treatment) selama 4 kali pembelajaran di kelas. Data hasil belajar mahasiswa selama mengikuti pembelajaran akan dianalisis di penelitian ini.

Instrumen yang digunakan dalam penelitian ini adalah tes, angket dan lembar observasi. Tes digunakan untuk mengetahui hasil belajar mahasiswa. Lembar observasi digunakan untuk mengetahui aktivitas mahasiswa dan kemampuan dosen dalam mengelola pembelajaran.

Teknik analisa data yang digunakan dalam penelitian ini adalah (1) analisis instrumen hasil belajar yang terdiri dari validitas dan reabilitas tes, (2) analisis data hasil belajar yang diperoleh dari hasil tes tertulis, (3) analisis data observasi aktivitas siswa, dan kemampuan dosen dalam mengelola pembelajaran.

\section{Hasil dan Pembahasan}

Efektivitas pembelajaran biologi dapat diketahui berdasarkan hasil belajar mahasiswa dan observasi kegiatan pembelajaran yang dilakukan peneliti di dalam kelas.

Tabel 1. Analisis Hasil Belajar Mahasiswa Pendidikan Biologi

\begin{tabular}{|c|c|}
\hline Kelas & Nilai Rata-rata \\
\hline Eksperimen & 86,63 \\
\hline Kontrol & 79,71 \\
\hline
\end{tabular}

Berdasarkan data tabel 1 dapat dilihat bahwa hasil belajar mahasiswa kelas experimen dan kelas kontrol berada pada kategori tinggi dengan nilai rata-rata kelas experiment 86,63 dan nilai rata-rata kelas kontrol 79,71. Sehingga dapat diambil kesimpulan bahwa hasil belajar mahasiswa kelas experimen yang menggunakan aplikasi edmodo lebih tinggi daripada yang menggunakan konvensional.

Berdasarkan analisis data hasil belajar ditemukan data bahwa ketuntasan belajar kelas experiment mencapai $84 \%$ sedangkan ketuntasan belajar kelas kontrol $66 \%$. Hal ini membuktikan bahwa pembelajaran menggunakan aplikasi Edmodo efektif terhadap pembelajaran.

Berdasarkan hasil lembar observasi terhadap keefektifan pembelajaran pada kelas kelas experiment maupun kelas kontrol sama sama berada pada kategori efektif sehingga dapat disimpulkan bahwa penggunaan aplikasi Edmodo tefektif dalam pembelajaran di kelas.

Analisis normalitas data dilakukan untuk mengetahui apakah data berdistribusi normal atau tidak. Uji normalitas menggunakan uji Shapiro wilk karena jumlah masing-masing data dibawah 50 siswa. Pengujian dilakukan menggunakan aplikasi SPSS dengan taraf signifikansi $\alpha=$ $5 \%$ atau $\alpha=0,05$. Adapun kriteria pengujian: Jika $p$-value $\geq \alpha=0,05$ maka dapat disimpulkan bahwa data tersebut berdistribusi normal. Sedangkan jika pvalue $<\alpha=0,05$ maka dapat disimpulkan 
bahwa data yang diteliti tidak berdistribusi normal.

Tabel 2. Hasil Uji Normalitas Hasil Belajar Mahasiswa Kelas Experiment Dan Kelas Kontrol

\begin{tabular}{|c|c|c|c|}
\hline \multirow{2}{*}{ Kelompok Belajar } & \multicolumn{3}{|c|}{ Shapiro-Wilk } \\
\cline { 2 - 4 } & Statistic & df & Sig. \\
\hline Kelas Experimen & .950 & 44 & .058 \\
\hline Kelas Kontrol & .960 & 41 & .157 \\
\hline
\end{tabular}

Berdasarkan tabel hasil uji normalitas memiliki skor signifikansi kelas experiment 0,056 . Karena nilai $0,056>0,05$ maka dapat disimpulkan bahwa data posttest kelas experiment berdistribusi normal. Sedangkan hasil uji normalitas pada kelas kontrol memiliki nilai signifikansi 0,157 . Karena nilai $0.157>0,05$ maka data posttest kelas kontrol berdistribusi normal.

Selanjutnya dilakukan uji homogenitas untuk menyelidiki sama atau tidak variansi kedua sampel. Uji ini dilakukan sebagai prasyarat dalam analisis Independent Sample T-test. Data yang memenuhi syarat adalah jika varian sama atau subjek berasal dari kelompok yang homogen. Uji yang digunakan adalah uji Levene's Test. Nilai Levene's Test dapat dilihat pada tabel output independent sample t-test menggunakan SPSS. Pada uji Levene's Test digunakan taraf signifikan $\mathrm{a}=5 \%$ atau $\mathrm{a}=0,05$. Adapun kriteria pengujian: Jika nilai sig $>0,05$ maka varians data adalah homogen. Jika nilai sig $<0,05$ maka varians data adalah tidak homogen.

Tabel 3. Uji Homogenitas Hasil Belajar Mahasiswa

\begin{tabular}{|c|c|r|c|c|c|}
\hline \multicolumn{2}{|c|}{} & $\begin{array}{c}\text { Levene } \\
\text { Statistic }\end{array}$ & $d f 1$ & $d f 2$ & Sig. \\
\hline & $\begin{array}{c}\text { Based on } \\
\text { mean }\end{array}$ & .927 & 1 & 83 & .338 \\
\cline { 2 - 6 } & $\begin{array}{c}\text { Based on } \\
\text { median }\end{array}$ & .640 & 1 & 83 & .426 \\
\cline { 2 - 6 } $\begin{array}{c}\text { Hediajar } \\
\text { Based on } \\
\text { median } \\
\text { and with } \\
\text { adjusted } \\
\text { df }\end{array}$ & .640 & 1 & 83 & .426 \\
\hline
\end{tabular}

\begin{tabular}{|l|c|c|c|c|c|}
\hline & $\begin{array}{c}\text { Based on } \\
\text { trimmed } \\
\text { mean }\end{array}$ & .848 & 1 & 83 & .360 \\
\hline
\end{tabular}

Setelah data dinyatakan berdistribusi normal dan homogen, maka memenuhi syarat dilakukan analisis statistik inferensial untuk menguji hipotesis dengan menggunakan statistik uji $\mathrm{t}$ (Independent Sample T-Test) dengan taraf signifikansi a $=0,05$. Dengan kriteria, jika $p$-value $=\mathrm{a}$ maka $\mathrm{H}_{0}$ diterima dan jika pvalue $<$ a maka $\mathrm{H}_{0} \quad$ ditolak. Pengujian hipotesis dimaksudkan untuk menjawab hipotesis penelitian yang telah diajukan.

Berdasarkan analisis ketuntasan klasikal hasil belajar mahasiswa pendidikan biologi di kelas experiment mencapai $84 \%$. Nilai ketuntasan ini termasuk kategori tinggi dan baik bagi proses pembelajaran, walaupun harapan pengajar adalah ketuntasan yang dicapai harusnya mencapai $100 \%$ sehingga mahasiswa dapat dikatakan seluruhnya menguasai pembelajaran. Presentase ketuntasan klasikal adalah hal yang pentingdiketahui untuk mengukur keefektifan proses pembelajaran di dalam kelas.

Berdasarkan analisis keefektifan pembelajaran yang dilakukan observer dapat dikatakan bahwa penggunaan aplikasi Edmodo efektif untuk pembelajaran di dalam kelas. Perbedaan mencolok antara kelas yang diajarkan dengan menggunakan aplikasi Edmodo dengan yang tidak yaitu adanya kepraktisan pengelolaan pembelajaran dan penugasan kepada mahasiswa. Kelas yang menggunakan aplikasi Edmodo leih teratur dalam penugasan, mereka bisa mengumpulkan tugas lebih tepat waktu karena jika waktu yang ditentukan di dalam aplikasi habis mahasiswa tidak lagi dapat mengirimkan tugas tersebut. Berbeda dengan kelas kontrol mahasiswa yang terlambat mengumpulkan tugas masih dapat pengumpulkan di hari lain. Ujian yang dilakukan menggunakan aplikasi Edmodo juga lebih baik dan efektif dalam menentukan nilai. Mahasiswa dapat melihat langsung nilai mereka segera setelah mengirimkan lembar jawaban, soal yang 
diberikan tersimpan di aplikasi sehingga daapat digunakan kembali oleh pengajar di kelas lainnya. Begitupun dengan proses pemberian materi dimana dosen dapat memberikan bacaan atau video yang lebih terarah kepada mahasiswa di kelasnya sehingga apa yang mereka pelajari bisa lebih terstruktur.

\section{Simpulan}

Kesimpulan yang dapat diambil dari penelitian ini adalah: 1) Ketuntasan klasikal mahasiswa yang diajarkan menggunakan aplikasi Edmodo mencapai $82 \%$; dan 2) Penggunaan aplikasi Edmodo memiliki pengaruh terhadap keefektifan pembelajaran di kelas.

\section{Daftar Pustaka}

[1] Adittia, A. (2017). Penggunaan Media Pembelajaran Audiovisual untuk Meningkatkan Hasil Belajar IPS pada Siswa Kelas IV SD. Mimbar Sekolah Dasar, 4(1), 9-20.

[2] Angraini, M. R., Muharini, R., \& Lestari, I. (2018). Penerapan Blended Learnng Berbasis Edmodo Terhadap Minat dan Hasil Belajar Siswa SMA Negeri 9 Pontianak. Jurnal Pendidikan Dan Pembelajaran Khatulistiwa, 7(2), 1-12.

[3] Darmawan, Deni. (2014). Pengembangan E-Learning Teori dan Desain. Bandung: Remaja Rosdakarya.

[4] Dharmawati. (2017). Penggunaan Media e-Learning Berbasis Edmodo dalam Pembelajaran English for Business. Jurnal Sistem Informasi $1(1): 43-49$.

[5] Miftakh, F., \& Samsi, Y. S. (2015). Penggunaan Media Audio Visual
Dalam Meningkatkan Kemampuan Menyimak Mahasiswa. Jurnal ilmiah Solusi, 6(3), 17-24.

[6] Sugiyono. (2018). Metode Penelitian Kuantitatif, Kualitatif, dan $R \& D$. Bandung: Alfabeta.

[7] Vania, P. F., Setiawan, W., Fany, A., \& Wijaya, C. (2018). Edmodo as WebBased Learning to Improve Student' $\mathrm{s}$ Cognitive and Motivation in Learning Thermal Physics. Journal of Science Learning, 1(3), 110-115. https://doi.org/10.17509/jsl.v1i3.11796

[8] Yustinaningrum, B. (2018). The Implementation of E-Learning Webbased Model Centric Course (Edmodo) toward The Mathematics' Interest and Learning Outcomes Bettri. Jurnal Pendidikan Matematika, 9(1), 25-32.

[9] Zamrotul, A., \& Durinta, P. (2015). Penggunaan Edmodo Sebagai Media Pembelajaran E-Learning Pada Mata Pelajaran Otomatisasi Perkantoran Di SMKN 1 Surabaya. Jurnal Pendidikan Administrasi Perkantoran (JPAP), 3(3), 1-13. https://jurnalmahasiswa.unesa.ac.id/ind ex.php/jpap/article/view/12541.

\section{Profil Penulis}

Novelina Andriani Zega, S.P.d., M.Pd. adalah dosen tetap di Yayasan Perguruan Tinggi Nias. Beliau mengajar di FPMIPA Prodi Pendidikan Biologi, IKIP Gunungsitoli. Penulis Lulus S1 pada tahun 2013 di Prodi Pendidikan Biologi IKIP Gunungsitoli dan Lulus S2 pada tahun 2016 di Prodi Pendidikan Biologi Universitas Negeri Medan. 